\title{
Structurally modified ibogaine analogs exhibit differing affinities for NMDA receptors
}

\author{
Richard T. Layer ${ }^{\text {a. }}$, Phil Skolnick ${ }^{\text {a }}$. Craig M. Bertha ${ }^{\text {b.J }}$, Upul K. Bandarage ${ }^{c}$, \\ Martin E. Kuehne ${ }^{c}$, Piotr Popik ${ }^{\text {a.d }}$ \\ a Laboralon of Neuroscience. National Institute of Diabetes. Digestire and Kidney Diseases. National Institutes of Health. Bethesda, MD. LSA \\ 'Laboraton of Medicinal Chemistn. National institute of Diabetes. Digessire and Kidney Diseases. National Institutes of Health. Bethesda, MD. USA \\ Department of Chemistri. Unicersity of Vermont. Cook Phisical Science Building. Burlington. VT. USA \\ Instimute of Pharmacologv. Polish Academy of Scrences. Krakow, Poland \\ Received 4 January 1996: revised 27 March 1996; accepted 12 April 1996
}

\begin{abstract}
Based on both preclinical findings and anecdotal evidence in man. the psychoactive indole alkaloid ibogaine has been suggested to have anti-addictive properties. Previous studies indicate that blockade of NMDA receptors may mediate at least some of the putative anti-addictive actions of ibogaine. The potencies of a series of ibogaine analogs to inhibit $(+)-\left[3-{ }^{3} \mathrm{H}\right] 5-$ methyl-10.11-dihydro-5 H-dibenzo[a,d]cyclohepten-5,10-imine ([ $\left.\left.{ }^{3} \mathrm{H}\right] \mathrm{MK}-801\right)$ binding to NMDA receptors were examined. This series of analogs included the putative ibogaine metabolite $O$-desmethylibogaine, its metabolism resistant analog $O$ - $t$-butyl-O-desmethylibogaine, the iboga alkaloids ( \pm )-ibogamine, $( \pm$ )-coronaridine, tabernanthine, harmaline, and the indolotropanes endo-3-(1-methylindol-2-yl)-8-methyl-8-azabicyclo[3.2.1 loctane (RS 075194-190), exo-3-(1-methylindol-2-yl)-8-methyl-8-azabicycld [3.2.1 Joctane (RS 075237-190) and endo-3-(indol-2-yl)-8methyl-8-azabicyclo[3.2.1] Joctane (RS 025989-190). Among these compounds, ibogaine was the most potent inhibitor of [ ${ }^{3} \mathrm{H}$ ]MK-801 binding $\left(K_{1}=\sim 1.2 \mu \mathrm{M}\right)$, whilst the compounds with the greatest structural similarity to ibogaine, $O$-desmethylibogaine and $O$ - $t$-butyl$O$-desmethylibogaine were less potent $\left(K_{i}=\sim 5.5\right.$ and $179.0 \mu \mathrm{M}$, respectively). In morphine-dependent mice, ibogaine, but not $O$-desmethylibogaine or $O$-i-butyl-O-desmethylibogaine, attenuated naloxone precipitated withdrawal jumping. These findings are consistent with the hypothesis that inhibition of the expression of morphine dependence by ibogaine is related to its NMDA receptor antagonist properties.
\end{abstract}

Reywords: NMDA receptor: Ibogaine; $O$-Desmethylibogaine; Morphine: Naloxone

\section{Introduction}

Ibogaine is a psychoactive indole alkaloid originally isolated from the roots of the West African shrub Tabernanthe iboga. Ibogaine containing extracts were originally used in the religious rites of several West African secret societies. During the past decade. both preclinical studies (Aceto et al., 1990; Cappendjik and Dzoljic, 1993: Dzoljic et al., 1988: Glick et al.. 1991, 1992. 1994: Sershen et al., 1993) and anecdotal reports (Lotsof. 1985, 1986, 1995) indicate that ibogaine can interfere with dependence and

\footnotetext{
"Corresponding author. NIDDK/NIH, Building 8. Room 111. Bethesda. MD 20892-0008. USA. Tel.: +1 3014968717 : fax: +1301 402 2872: e-mail: rtlayer@helix.nih.gov

'Current address: Food and Drug Administration. HFD-570, 5600

Fiahers Lane, Rockville. MD 20857. USA.
}

withdrawal phenomena associated with a number of abused substances including cocaine and morphine (for review, see Popik et al., 1995b).

While the neurochemical bases for the these putative 'anti-addictive' actions of ibogaine remain unclear, several recent reports (Mash et al., 1995; Popik et al., 1994. 1995a: Sweetnam et al., 1995) have shown that at pharmacologically relevant concentrations, ibogaine acts as an NMDA receptor antagonist. Thus, ibogaine competitively inhibits $(+)-\left[3--^{3} \mathrm{H}\right] 5$-methyl-10,11-dihydro- $5 \mathrm{H}$-dibenzo[a,d]cyclohepten-5,10-imine $\left.\left({ }^{3} \mathrm{H}\right] \mathrm{MK}-801\right)$ and [piperidyl3,4- $\left.{ }^{3} \mathrm{H}(N)\right)$ - $(N-(1-(2$ thienyl)cyclohexyl)-3,4-piperidine) $\left(\left[{ }^{3} \mathrm{H}\right] \mathrm{TCP}\right)$ binding to NMDA receptors (Mash et al., 1995; Popik et al.. 1994, 1995a; Sweetnam et al., 1995), blocks glutamate-induced cell death (Popik et al., 1995a), and produces a voltage-dependent block of NMDA currents (Mash et al., 1995; Popik et al.. 1995a). Moreover, ibo- 
gaine substitutes for MK-801 in a drug discrimination paradigm, and the ability of ibogaine to attenuate naloxone-precipitated jumping in morphine-dependent mice is abolished by glycine (Popik et al., 1995a). This latter observation is consistent with the hypothesis that ibogaine attenuates the expression of opiate dependence through a use-dependent block of NMDA receptors, and supports an emerging body of evidence indicating that NMDA receptor antagonists attenuate the tolerance and withdrawal associated with opioid dependence (Ben-Eliyahu et al.. 1992; Higgins et al., 1992; Kolesnikov et al.. 1994; Marek et al., 1991; Rasmussen et al., 1991; Tiseo et al., 1994; Tiseo and Inturrisi, 1993; Trujillo and Akil, 1991, 1995). Nonetheless, pharmacologically relevant concentrations of ibogaine have been reported to affect a number of other systems which may be relevant to drug abuse including $\kappa$ opiate receptors (Deecher et al., 1992; Pearl et al., 1995; Sweetnam et al., 1995), $\sigma$ receptors (Bowen et al., 1995; Mach et al., 1995; Popik et al., 1995b), and dopamine transporters (Sershen et al., 1992; Sweetnam et al., 1995).

A strategy which has been successfully employed to define loci of drug action is the synthesis and evaluation of structural derivatives of an active compound. Based on this strategy, it was hypothesized that if ibogaine attenuates the expression of opiate dependence through a blockade of NMDA receptors, then modification of this compound could lead to derivatives whose in vivo actions in this measure would parallel their in vitro affinities at NMDA receptors. To implement this strategy, we synthesized a number of ibogaine derivatives including $O$-desmethylibogaine (a putative ibogaine metabolite [Mash et al., 1995; Pearl et al., 1995]) and $O-t$-butyl-O-desmethylibogaine (an analog designed to resist $O$-dealkylation), and the potencies of these compounds to inhibit $\left[{ }^{3} \mathrm{H}\right] \mathrm{MK}-801$ binding to NMDA receptor were compared to the parent alkaloid. Several of these compounds exhibiting a range of affinities at NMDA receptors were subsequently assessed for the ability to inhibit naloxone-induced withdrawal jumping in morphine-dependent mice. We report here that among structurally related derivatives of ibogaine. only the parent compound (which exhibited the highest affinity for NMDA receptors) was able to attenuate withdrawal-induced jumping in mice.

\section{Materials and methods}

\subsection{Animals}

Male NIH Swiss mice (20-25 g, HSD, Veterinary Resources Branch, NIH, Bethesda, MD, USA). SpragueDawley rats (200-250 g. Taconic Farms, Germantown, NY, USA), and Hartley guinea-pigs (300-500 g, Charles River Laboratories, Wilmington, MA, USA) were housed under standard laboratory conditions (lights on at 06:00 h, lights off $18: 00 \mathrm{~h}$; room temperature $23 \pm 1^{\circ} \mathrm{C}$ ) with chot and tap water available ad libitum.

\subsection{Drugs}

Morphine, ibogaine $\mathrm{HCl}$. and TCP were obtained from NIDA (Rockville, MD, USA). Naloxone was obtained from Dr. K. Rice (NIDDK. NIH, Bethesda, MD, USA). Memantine was the gift of Merz \& Co. (Germany). Harmaline was obtained from Dr. J. Daly (NIDDK, NIH). Tabernanthine was obtained from Drs. P. Potier and C. Kan (Centre National de la Recherche Scientifique, Institut de Chimie des Substances Naturelles, Gif-sur-Yvette Cédex, France). ( \pm Ibogamine $\mathrm{HCl},( \pm)$ coronaridine $\mathrm{HCl}$, ( \pm )4-methyl-4-desethylcoronaridine $\mathrm{HCl}$, and $( \pm)$ 4-desethylcoronaridine, $\mathrm{HCl}$ were synthesized (M.E.K. and U.K.B.) as described (Glick et al.. 1994). (+)U-50488, $(-) \mathrm{U}-50488$ and nor-binaltorphamine were synthesized (C.M.B.) as described (De Costa et al., 1987; Lipkowski et al., 1986). $O$-Desmethylibogaine $\mathrm{HCl}$ and $O$-t-butyl- $O$-desmethylibogaine were synthesized (C.M.B.) as described below. Endo-3-(1-methylindol-2-yl)-8-methyl-8-azabicyclo[3.2.1 ]octane (RS 075194-190), exo-3-(1-methylindol-2-yl)-8-methyl-8-azabicyclo[3.2.1 ]octane (RS 075237190) and endo-3-(indul-2-y1)-8-methyl-8-azabicyclo[3.2.1]octane (RS 025989-190) were kindly donated by Dr. David Repke (Syntex Discovery Research, Palo Alto, CA, USA). Other chemicals were obtained from Sigma Chemical Company (St. Louis, MO, USA).

Morphine (free base) was converted to the $\mathrm{HCl}$ salt by addition of a small volume of $1 \mathrm{~N} \mathrm{HCl}$ and subsequently dissolved in saline, the $\mathrm{pH}$ was adjusted to 7 with $\mathrm{NaOH}$. Naloxone and memantine were dissolved in saline. Tabernanthine was dissolved in $10 \%$ ethanol in $0.1 \mathrm{~N} \mathrm{HCl}$, $O$ - $t$-butyl- $O$-desmethylibogaine was dissolved in $0.1 \mathrm{~N}$ $\mathrm{HCl}$, and all other compounds were dissolved in $\mathrm{H}_{2} \mathrm{O}$ before dilution into appropriate buffers (see below). The doses of ibogaine used in this study were previously shown to be within the range that inhibited naloxone-precipitated jumping behavior in morphine-dependent mice (Popik et al.. 1995a). All injections $(0.2 \mathrm{ml})$ were administered i.p.

\subsection{Morphine dependence and withdrawal}

Mice were rendered morphine dependent and withdrawal precipitated with naloxone as previously described (Popik et al., 1995a; Popik and Skolnick, 1995). In brief, mice were administered morphine $(30 \mathrm{mg} / \mathrm{kg}$, twice daily, at $09: 30 \mathrm{~h}$ and 17:30 h) for 3 days, and an additional last dose administered on the morning of the test (4th) day. $2 \mathrm{~h}$ and $15 \mathrm{~min}$ after the last dose of morphine, mice were injected with a test compound or vehicle. Mice were challenged with naloxone ( $4 \mathrm{mg} / \mathrm{kg}$ ) $45 \mathrm{~min}$ after administration of the test compound and immediately placed in transparent plastic cylinders ( $42 \mathrm{~cm}$ high, $19 \mathrm{~cm}$ diameter). 
The number of jumps was recorded during a 10-min test period. Animals were used only once. Immediately after the jumping session, some animals were placed on a rotorod $(4.6 \mathrm{rpm})$ for $30 \mathrm{~s}$. Data are presented as means \pm S.E.M. of the number of jumps in $10 \mathrm{~min}$. Data were evaluated by Kruskal-Wallis analysis of variance followed by Dunn's Multiple Comparisons test for comparison of individual groups, with $P<0.05$ accepted as significant.

\subsection{Radioligand binding}

$\left[{ }^{3} \mathrm{H}\right] \mathrm{MK}-801$ (S.A. $22.5 \mathrm{Ci} / \mathrm{mmol}$ : Dupont-NEN. Boston, MA) binding was assayed in extensively washed membranes prepared from rat forebrain. The methods employed for tissue preparation and radioligand binding were identical to those described by Popik et al. (1994). To generate competition curves, membranes were incubated for $2 \mathrm{~h}\left(25^{\circ} \mathrm{C}\right)$ with $4-5 \mathrm{nM}$ of $\left[{ }^{3} \mathrm{H}\right] \mathrm{MK}-801$ in the presence of $30 \mu \mathrm{M}$ glycine and $30 \mu \mathrm{M}$ glutamate. Nonspecific binding was defined with 1-[1-(2-thienyl)cyclohexyl]piperidine (TCP) hydrochloride $(100 \mu \mathrm{M})$.

$\left[{ }^{3} \mathrm{H}\right] \mathrm{U}-69593$ (S.A. $47.4 \mathrm{Ci} / \mathrm{mmol}$ : Dupont-NEN) binding was assayed in membranes prepared from rat, mouse. and guinea-pig forebrains. The methods employed for tissue preparation and radioligand binding were essentially as described (Lahti et al., 1985). In brief, forebrains were homogenized in ice-cold $50 \mathrm{mM}$ Hepes- $\mathrm{NH}_{4} \mathrm{OH}(\mathrm{pH} 7.4)$ and centrifuged at $30000 \times g$ for $10 \mathrm{~min}$. The pellet was resuspended in Hepes- $\mathrm{NH}_{4} \mathrm{OH}$ buffer, recentrifuged $(20000 \times \mathrm{g}, 20 \mathrm{~min})$ and resuspended in buffer to a volume of $1: 50 \mathrm{w} / \mathrm{v}$. Assays were performed in duplicate using polystyrene 96-well titre plates (Brandel. Gaithersburg, MD, USA). Membranes $(500 \mu$ l representing $\sim 100$

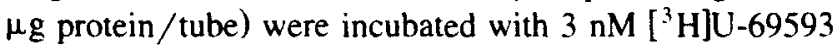
in $50 \mathrm{mM}$ Hepes- $\mathrm{NH}_{4} \mathrm{OH}$ buffer containing drugs and/or buffer in a total volume of $1 \mathrm{ml} /$ assay. Non-specific binding was defined by $100 \mu \mathrm{M}(-) \mathrm{U}-50,488$. Assays were initiated with tissue and terminated after $30 \mathrm{~min}$ $\left(30^{\circ} \mathrm{C}\right)$ by filtration on Whatman $\mathrm{GF} / \mathrm{B}$ filters using a Brandel MB-48R manifold. The filters were washed 3 times with $1 \mathrm{ml}$ Hepes- $\mathrm{NH}_{4} \mathrm{OH}$ buffer and the radioactivity retained on the filters measured in a Beckman LS-5801 liquid scintillation counter. Data were analyzed by iterative curve fitting using GraphPad-Inplot, Version 4.01.

\subsection{Synthesis}

\subsection{1. instrumentation and methods}

Proton NMR spectra were recorded in $\mathrm{CDCl}_{3}$ on a Varian Gemini-300 spectrometer and the data are reported in the following format: chemical shift (all relative to $\mathrm{Me}_{4} \mathrm{Si}$ ), multiplicity ( $\mathrm{s}=$ singlet, $\mathrm{d}=$ doublet, $\mathrm{t}=$ triplet. $\mathrm{q}=$ quartet, $\mathrm{br}=$ broad, $\mathrm{m}=$ multiplet, ap = apparent), integration. coupling constants, and exchangeability after $\mathrm{D}_{2} \mathrm{O}$ addition. Electron impact (EI) mass spectra were recorded on a VG Micromass $7070 \mathrm{~F}$ spectrometer. Thin- layer chromatography (TLC) was performed on Analtech silica gel GHLF $0.25-\mathrm{mm}$ plates. Preparative TLC was performed on Analtech silica gel GF $2.00-\mathrm{mm}$ plates. Column chromatography was performed with Fluka silica gel 60 (mesh 220-440). Elemental microanalyses were performed by Atlantic Microlab. Melting points were recorded on a Thomas-Hoover capillary apparatus and are uncorrected.

\subsubsection{Preparation of o-t-bunl-o-desmethylibogaine (CB- 609.2)}

A solution of $O$-desmethylibogaine (Bartlett et al., 1958) in freshly distilled $N . N$-dimethylformamide di-t-butyl acetal $(1.2 \mathrm{ml} .5 .0 \mathrm{mmol})$ was stirred at $110^{\circ} \mathrm{C}$ under an atmosphere of argon for $22.5 \mathrm{~h}$ and then at room temperature for $9.5 \mathrm{~h}$. The reaction mixture was concentrated on a high vacuum line at room temperature and the residue was dissolved in $N . N$-dimethylformamide di-t-butyl acetal (1.0 $\mathrm{ml}, 4.2 \mathrm{mmol}$ ) and heated for $14 \mathrm{~h}$ at $110^{\circ} \mathrm{C}$. TLC indicated incomplete reaction so the reagent was evaporated on a high vacuum line and the residue was taken up in chloroform $(20 \mathrm{ml})$ and this solution was washed with half saturated brine $(10 \mathrm{ml})$. The chloroform layer was dried $\left(\mathrm{Na}_{2} \mathrm{SO}_{4}\right)$ and was concentrated to dryness. A mixture of the residue and benzene was concentrated to dryness and the resulting residue was dissolved in $N . N$-dimethylformamide di-t-butyl acetal $(2.4 \mathrm{ml}, 10 \mathrm{mmol})$ and stirred under argon at $110^{\circ} \mathrm{C}$ for $20 \mathrm{~h}$. TLC indicated complete reaction. The excess reagent was evaporated utilizing a high vacuum line. The residue was taken up in chloroform and the solvent was evaporated on silica gel 60 (mesh 220-440. 2 $\mathrm{g}$ ). The reaction product was purified on a silica gel column $(50 \mathrm{~g})$ by eluting with chloroform $/$ methanol $/ 28 \%$ $\mathrm{NH}_{4} \mathrm{OH}(97: 3: 0.3)$. The fractions containing the major product $\left(R_{f}=0.54\right.$ in above solvent) were pooled and concentrated, yielding $106 \mathrm{mg}$ of crude product. This was purified twice by preparative TLC with $2 \times 2 \mathrm{~mm}$ Analtech silica gel plates with the eluting solvent chloroform / methanol $/ 28 \% \mathrm{NH}_{4} \mathrm{OH}(98: 2: 0.2$ first set of plates, $96: 4: 0.4$ second). This yielded a yellow foam, $70 \mathrm{mg}$, that was crystallized from ethanol/water, yielding $51 \mathrm{mg}$ of yellow crystalline solid. This was further purified on one preparative TLC plate with the eluting solvent chloroform/methanol/28\% $\mathrm{NH}_{4} \mathrm{OH}(98: 2: 0.2)$ yielding $46 \mathrm{mg}$ of yellow crystalline residue. This was recrystallized from ethanol/water to yield $36 \mathrm{mg}(17 \%)$, mp $200-202^{\circ} \mathrm{C} ;{ }^{\prime} \mathrm{H}$ NMR $\left(\mathrm{CDCl}_{3}\right): \delta 7.54$ (br s, $1 \mathrm{H}$, ex. w/D $\left./ \mathrm{D}_{2} \mathrm{O}\right), 7.11$ (d. $1 \mathrm{H}, J=8.7 \mathrm{~Hz}), 7.06(\mathrm{~d}, 1 \mathrm{H}, J=1.9 \mathrm{~Hz}), 6.43(\mathrm{dd}, 1 \mathrm{H}$, $J=2.4,8.5 \mathrm{~Hz}), 3.33(\mathrm{~m}, 2 \mathrm{H}), 3.12(\mathrm{~m}, 2 \mathrm{H}), 2.97(\mathrm{~m}$, 1H), $2.90(\mathrm{~m}, 1 \mathrm{H}), 2.60(\mathrm{~m}, 1 \mathrm{H}), 2.03(\mathrm{t} .1 \mathrm{H}, J=12.3$ $\mathrm{Hz}$ ), 1.79 (m. 2H), $1.68(\mathrm{qd}, 1 \mathrm{H}, J=3.4,13.1 \mathrm{~Hz}$ ), 1.51 $(\mathrm{m}, 4 \mathrm{H}), 1.34(\mathrm{~s}, 9 \mathrm{H}) .1 .21(\mathrm{~m}, 1 \mathrm{H}), 0.89(\mathrm{t}, 3 \mathrm{H}, J=7.0$ $\mathrm{Hz}$ ): MS (El) $m /: 352\left(\mathrm{M}^{+\cdot}\right), 296\left(\mathrm{M}^{+\cdot}-\mathrm{C}_{4} \mathrm{H}_{8}\right)$; HRMS $m / z$ 352.2513, experimental; 352.2515, calculated; Anal. calcd. for $\mathrm{C}_{23} \mathrm{H}_{32} \mathrm{~N}_{2} \mathrm{O}(\mathrm{C}, \mathrm{H}, \mathrm{N})$. 


\section{Results}

The $K_{\mathrm{i}}$ values for ibogaine and structurally related derivatives to inhibit $\left[{ }^{3} \mathrm{H}\right] \mathrm{MK}-801$ binding to NMDA receptors in rat forebrain are shown in Table 1 . The $K_{\mathrm{i}}$ value obtained for ibogaine $(1.1 \pm 0.03 \mu \mathrm{M})$ is consistent with our previous results (Popik et al., 1994. 1995a) as well as the values reported by Mash et al. (1995) in human brain obtained at autopsy. The putative ibogaine metabolite $\boldsymbol{O}$-desmethylibogaine (12-hydroxyibogamine) [Mash et al., 1995; Pearl et al., 1995], and the chemically related iboga alkaloids ( \pm )ibogamine, $( \pm)$ coronaridine and tabernanthine were $\sim 5$-10-fold less potent than the parent alkaloid (Table 1). The $\sim 5$-fold lower affinity of $O$-desmethylibogaine reported here is consistent with $\mathrm{IC}_{50}$ values 4-6-fold lower than ibogaine in human brain (Mash et al., 1995). Other compounds bearing a structural similarity to ibogaine. including harmaline. $( \pm)$ 4-methyl-4-desethylcoronaridine, $( \pm)$ 4-desethylcoronaridine and $O-t$ butyl- $O$-desmethylibogaine were $>45$-fold less potent than ibogaine $\left(K_{\mathrm{i}}=47-252 \mu \mathrm{M}\right.$; Table 1). The potencies of a series of indolotropanes, a class of ibogaine congeners which retain the basic structural features of ibogaine ( $\mathrm{Re}$ pke et al., 1994), were also examined. The most potent indolotropane, endo-3-(1-methylindol-2-yl)-8-methyl-8azabicyclo[3.2.1]octane (RS 075194-190) was $\sim 15$-fold less potent than ibogaine $\left(K_{\mathrm{i}}=\sim 16.8 \mu \mathrm{M}\right)$ while the other indolotropanes, exo-3-( 1 -methylindol-2-yl)-8-methyl8-azabicyclo[3.2.1] Joctane (RS 075237-190; $K_{\mathrm{i}}=48.6 \mu \mathrm{M}$ ) and endo-3-(indol-2-yl)-8-methyl-8-azabicyclo[3.2.1]oc- tane (RS 025989-190: $K_{\mathrm{i}}=57 \mu \mathrm{M}$ ), exhibited even lower affinities in this measure.

The potencies of ibogaine, $O$-desmethylibogaine, and $O$ - $t$-butyl-O-desmethylibogaine to inhibit $\left[{ }^{3} \mathrm{H}\right] \mathrm{U}-69593$ binding to brain $\kappa$-opioid receptors are shown in Table 2. Since radioligand binding to $\kappa$-opioid receptors varies among species (Lahti et al., 1985), these ligands were examined in membranes from rat, mouse and guinea-pig. Inclusion of the stereoisomers of $\mathrm{U}-50488$ as positive controls demonstrated that the $(+)$-isomer was $>3$ orders of magnitude less potent than the corresponding ( - )-isomer. Moreover. the $\mathrm{IC}_{50}$ value obtained for these isomers is consistent with literature values (Lahti et al., 1985; Nock et al., 1990). The $\mathrm{IC}_{50}$ of ibogaine $(13-29.8 \mu \mathrm{M})$ to inhibit radioligand hinding to $\mathrm{k}$-opioid receptors is consistent with the values reported by Sweetnam et al. (1995) but slightly higher than reported by Repke et al. (1994) and Deecher et al. (1992). $O$-Desmethylibogaine was $\sim 10$-fold more potent than ibogaine (consistent with Pearl et al., 1995), and $O$ - $t$-butyl- $O$-desmethylibogaine equipotent with the parent compound, respectively (Table 3 ).

Based on the affinities of $O$-desmethylibogaine and $O$ - $t$-butyl-O-desmethylibogaine for NMDA and $\kappa$-opioid receptors. we evaluated the ability of these ibogaine derivatives to attenuate naloxone precipitated jumping in morphine-dependent mice (Table 3). Jumping was not observed in either saline-treated mice challenged with naloxone or morphine-dependent mice challenged with saline (data not shown). The NMDA receptor antagonist memantine (Bormann, 1989) was used as a positive con-

Table 1

Inhibition of $\left[{ }^{3} \mathrm{H}\right] \mathrm{MK}-801$ binding to NMDA receptors by ibogaine analogs

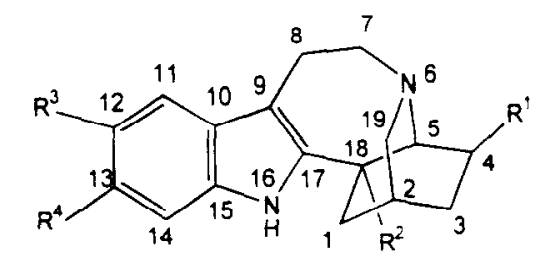

\begin{tabular}{|c|c|c|c|c|c|}
\hline Compound & RI & $\mathrm{R} 2$ & R3 & R4 & $K_{1}(\mu \mathrm{M})$ \\
\hline Ibogaine & $\mathrm{CH}_{2} \mathrm{CH}_{3}$ & $\mathrm{H}$ & $\mathrm{OCH}_{3}$ & $\mathrm{H}$ & $1.11 \pm 0.03$ \\
\hline$O$-Desmethylibogaine & $\mathrm{CH}_{2} \mathrm{CH}_{3}$ & $\mathrm{H}$ & $\mathrm{OH}$ & $\mathrm{H}$ & $5.48 \pm 0.17$ \\
\hline$( \pm$ Ibogamine & $\mathrm{CH}_{2} \mathrm{CH}_{3}$ & $\mathrm{H}$ & $\mathbf{H}$ & H & $5.52 \pm 0.12$ \\
\hline$( \pm$ Coronaridine & $\mathrm{CH}_{2} \mathrm{CH}_{3}$ & $\mathrm{CO}_{2} \mathrm{CH}_{3}$ & $\mathrm{H}$ & $\mathrm{H}$ & $6.24 \pm 0.32$ \\
\hline Tabernanthine & $\mathrm{CH}_{2} \mathrm{CH}_{3}$ & $\mathrm{H}$ & $\mathrm{H}$ & $\mathrm{OCH}_{3}$ & $10.5 \pm 1.1$ \\
\hline ( \pm 4-Methyl-4-desethylcoronaridine & $\mathrm{CH}_{3}$ & $\mathrm{CO}_{2} \mathrm{CH}_{3} \mathrm{H}$ & $\mathrm{H}$ & $\mathrm{H}$ & $67.9 \pm 2.7$ \\
\hline O-t-Butyl-O-desmethylibogaine & $\mathrm{CH}_{2} \mathrm{CH}_{3}$ & $\mathrm{H}$ & $\mathrm{OC}\left(\mathrm{CH}_{i}\right)_{i}$ & $\mathbf{H}$ & $179 \pm 13$ \\
\hline$( \pm$ 4-Desethylcoronaridine & $\mathrm{H}$ & $\mathrm{CO}_{2} \mathrm{CH}_{3}$ & $\mathrm{H}$ & $\mathrm{H}$ & $252 \pm 28$ \\
\hline
\end{tabular}

$\left[{ }^{3} \mathrm{H}\right] \mathrm{MK}-801(4 \mathrm{nM})$ binding to rat forebrain membranes was assayed as described in Materiats and methods. Non-specific binding was defined with 100 $\mu \mathrm{M}$ TCP. Basal $\left[{ }^{3} \mathrm{H}\right] \mathrm{MK}-801$ binding was $2.07 \pm 0.07 \mathrm{pmol} / \mathrm{mg}$ protein. Values represent mean $\pm S$.E.M. of 3 experiments. The $K$, of inemantine $(0.31 \pm 0.02 \mu \mathrm{M})$, a voltage-dependent channel blocker included as a positive control to validate the assay, is consistent with previously reported values (Kornhuber et al., 1989). The $K_{\mathrm{i}}$ values of other compounds tested were: harmaline $\left(K_{1}=46.6 \pm 5.2 \mu M\right)$, endo-3-(1-methylindol-2-yl)-8-methyl-8azabicyclo[3.2.1]octane (RS 075194-190; $\left.K_{1}=16.8 \pm 2.5 \mu \mathrm{M}\right)$. exo-3-(1-methylindol-2-yl)-8-methyl-8-azabicyclo/3.2.1 loctane (RS 075237-190; $K_{1}=$ $48.6 \pm 2.4 \mu \mathrm{M}$ ) and endo-3-(indol-2-yl)-8-methyl-8-azabicyclo(3.2.1 loctane (RS 025989-190: $K_{1}=57 \pm 4 \mu \mathrm{M}$ ). 
Table 2

Potencies $\left(\mathrm{IC}_{50}\right)$ of ibogaine analogs to inhibit $\left[{ }^{2} \mathrm{H}\right] \mathrm{U}-69.593$ binding to $\mathrm{k}$-opioid opiate receptors

\begin{tabular}{llcc}
\hline Compound & Rat & Mouse & Guinca-pig \\
\hline Ibogaine & $29.8 \pm 8.3 \mu \mathrm{M}$ & $13.8 \pm 0.6 \mu \mathrm{M}$ & $21.0 \pm 1.1 \mu \mathrm{M}$ \\
$O$-Desmethylibogaine & $0.28 \pm 0.11 \mu \mathrm{M}$ & $1.2 \pm 0.1 \mu \mathrm{M}$ & $2.6 \pm 0.5 \mu \mathrm{M}$ \\
$O-t$-Butyl-O-desmethylibogaine & $16.7 \pm 2.95 \mu \mathrm{M}$ & $12.4 \pm 0.3 \mu \mathrm{M}$ & $35.6 \pm 10.5 \mu \mathrm{M}$ \\
(+)U-50488 & $4.1 \pm 1.3 \mu \mathrm{M}$ & $1.0 \pm 0.1 \mu \mathrm{M}$ & $2.3 \pm 1.7 \mu \mathrm{M}$ \\
(-)U-50488 & $0.27 \pm 0.11 \mathrm{nM}$ & $1.1 \pm 0.1 \mathrm{nM}$ & $1.2 \pm 0.1 \mathrm{nM}$ \\
Nor-binaltorphamine & $0.46 \pm 0.15 \mathrm{nM}$ & $0.11 \pm 0.04 \mathrm{nM}$ & $0.10 \pm 0.01 \mathrm{nM}$ \\
\hline
\end{tabular}

$\left[{ }^{3} \mathrm{H}\right] \mathrm{U}-69593(3 \mathrm{nM})$ binding to forebrain membranes was assayed as described in Materials and methods. Non-specific binding was defined with $100 \mu \mathrm{M}$ $(-)$ U-50.488. Basal $\left[{ }^{3} \mathrm{H}\right](-69593$ binding to rat. mouse and guinea-pig membranes was $5.1 \pm 1.1 .18 .5 \pm 0.7$ and $37.7 \pm 2.7 \mathrm{fmol} / \mathrm{mg}$ protein. respectively. Values represent mean \pm S.E.M. of 3 experiments and are expressed as $\mathrm{IC}_{40}$ in $\mu \mathrm{M}$ or $\mathbf{n M}$ (boldface).

trol (Popik and Skolnick. 1995). and produced a significant, albeit incomplete attenuation of naloxone-induced jumping (Table 3). Consistent with previous reports (Dzoljic et al.. 1988: Aceto et al., 1990: Glick et al.. 1992: Popik et al., 1995a: but see also Sharpe and Jaffe. 1990: Francés et al.. 1992) ibogaine reduced naloxone-precipitated jumping, with the first statistically significant effect observed at $80 \mathrm{mg} / \mathrm{kg}$ i.p. (Table 3). Neither $O$-desmethylibogaine $(80 \mathrm{mg} / \mathrm{kg})$ nor $O$-t-butyl- $O$-desmethylibogaine (40 and $80 \mathrm{mg} / \mathrm{kg}$ ) inhibited naloxoneprecipitated jumping. At higher doses $(120 \mathrm{mg} / \mathrm{kg})$, both $O$-desmethylibogaine and $O$-t -butyl- $O$-desmethylibogaine produced profound ataxia and convulsions which precluded studying the actions of these alkaloids on naloxone-induced jumping. Ataxia and convulsions were also produced by the abbreviated ibogaine congener RS 075194-190 (60-250 mg/kg). At doses capable of reducing naloxone-precipitated jumping in morphine-dependent mice, neither ibogaine $(80 \mathrm{mg} / \mathrm{kg})$ nor memantine $(20$ $\mathrm{mg} / \mathrm{kg}$ ) impaired rotorod $(4.6 \mathrm{rpm}, 30 \mathrm{~s}$ trial) performance. Similarly, at the highest dose tested $(80 \mathrm{mg} / \mathrm{kg})$. neither $O$-desmethylibogaine nor $O$-t -butyl- $O$-des-

Table 3

Effects of ibogaine derivatives on naloxone-precipitated withdrawal jumping in morphine-dependent mice

\begin{tabular}{ll}
\hline Compounds(mg/kg) & $\begin{array}{l}\text { Contsol jumps / 10 min } \\
\text { (mean } \pm \text { S.E.M.) }[n]\end{array}$ \\
\hline Vehicle & $32.5 \pm 3.3[59]$ \\
Memantine (20) & $13.0 \pm 4.2 \times[20]$ \\
Ibogaine (40) & $22.0 \pm 5.4[10]$ \\
Ibogaine (80) & $19.7 \pm 4.2 \cdots[19]$ \\
O-Desmethylibogaine (80) & $28.2 \pm 5.3[14]$ \\
$O-t$-Butyl-O-desmethylibogaine (40) & $37.3 \pm 12.2[10]$ \\
$O-i$-Butyl- $O$-desmethylibogaine (80) & $26.3 \pm 11.3[10]$ \\
\hline
\end{tabular}

Effects of memantine, ibogaine and ibogaine analogs $O$-desmethylibogaine and $O$ - $t$-butyl- $O$-desmethylibogaine on naloxone-precipitated withdrawal jumping in morphine-dependent mice. Ataxia and convulsions were produced by the abbreviated ibogaine congener RS 075194-190 $(60-250 \mathrm{mg} / \mathrm{kg})$. Withdrawal was precipitated by naloxone and vertical jumps were counted for $10 \mathrm{~min}$. Values represent mean \pm S.E.M. of the number of jumps. Kruskal-Wallis statistic $K W=14.312$ (corrected for ties); $P=0.0263$. ' $P<0.05 ;{ }^{*} P<0.001$ vs. placebo. Dunn's multiple comparisons test. The doses in $\mathrm{mg} / \mathrm{kg}$ are given in parentheses. The number of mice tested are given in brackets. methylibogaine impaired rotorod performance (data not shown)

\section{Discussion}

The present results demonstrate that modification of the ibogaine molecule has a dramatic impact on affinity for NMDA receptors. Ibogaine binds to NMDA receptors with moderate affinity (Table 1: Mash et al.. 1995; Popik et al.. 1994, 1995a: Sweetnam et al., 1995), and the methoxy function at C-12 appears to be an important determinant for the ligand-receptor interaction. Thus, both $O$-demethylation ( $O$-desmethylibogaine) and phenolic deoxygenation (ibogamine) reduced the apparent affinity for NMDA receptors $\sim 5$-fold compared to ibogaine. Moreover, replacement of the methoxy function at $\mathrm{C}-12$ with the bulkier $t$-butoxy function ( $O$ - $t$-butyl- $O$-desmethylibogaine, designed to resist $O$-dealkylation in vivo) resulted in a $\sim 100$-fold decrease in affinity relative to ibogaine. The importance of the 12-methoxy moiety is further underscored by the apparent affinity of tabemanthine $\left(K_{\mathrm{i}}=\right.$ $\sim 10.5 \mu \mathrm{M})$. a positional isomer of ibogaine with the methoxy group at $\mathrm{C}-13$. These observations may be relevant to the hypothesis that the 'anti-addictive' properties of ibogaine are effected through a long-acting metabolite (Glick et al.. 1991), since $O$-desmethylibogaine has been claimed to be the principal metabolite of ibogaine (Pearl et al., 1995: Mash et al., 1995). If the effects of ibogaine on morphine dependence (Aceto et al., 1990; Dzoljic et al.. 1988; Glick et al., 1992; Popik et al., 1995a) are mediated via NMDA receptor blockade (Mash et al., 1995; Popik et al., 1995a), then the 5-fold lower affinity of $O$-desmethylibogaine indicates this compound would be a metabolite with diminished biological activity. Mash et al. (1995) have reached a similar conclusion, and reported that the potency of 0 -desmethylibogaine was $\sim 5$-fold lower than ibogaine for NMDA receptors in human brain.

Coronaridine, an ibogamine analog with a carbomethoxy moiety at position $\mathrm{C} 18$ ( R2 in Table 1) has an affinity similar to ibogamine $(6.2$ vs. $5.5 \mu \mathrm{M})$ which indicates that substitution at this position does not contribute substantially to the affinity of this alkaloid family at NMDA receptors. In contrast, substitution of the ethyl 
group at position C4 with a methyl group (4-methyl-4-desethylcoronaridine) or removal of the ethyl group (4-desethyl coronaridine) resulted in affinities reduced by $>1$ order of magnitude compared to the corresponding ethyl analogs. These findings indicate the ethyl moiety at position 4 ( $R 1$ in Table 1 ) is important for the interaction of ibogaine derivatives with NMDA receptors. Neither the structurally related alkaloid harmaline nor any of the indole tropanes tested exhibited a $K_{\mathrm{i}}<10 \mu \mathrm{M}$ for NMDA receptors. It should be noted that in some cases, racemic mixtures were used to determine affinity. Thus, the affinity of a potential active isomer would be underestimated.

Several reports have demonstrated that ibogaine also binds to $\kappa$-opioid receptors with moderate affinity (Deecher et al., 1992; Pearl et al., 1995; Sweetnam et al., 1995). While the affinity of ibogaine for $\kappa$-opioid receptors is slightly lower than for NMDA receptors, brain concentrations of ibogaine after pharmacologically relevant doses would be sufficient to occupy these receptors (Zetler et al., 1972). The recent report (Pearl et al.. 1995) that the apparent affinity of $O$-desmethylibogaine in calf cortex is $\sim 4$ times higher than ibogaine prompted us to compare the affinities of ibogaine, $O$-desmethylibogaine. and $O$ - $t$-butyl- $O$-desmethylibogaine for these receptors in several species. Interspecies comparisons were made since Lahti et al. (1985) have demonstrated differences in the percentage of total opioid binding sites which represent $\boldsymbol{k}$-opioid sites in rat, mouse and guinea-pig. Consistent with the report of Pearl et al. (1995). O-desmethylibogaine was $\sim 10$-fold more potent than ibogaine in inhibiting $\left[{ }^{3} \mathrm{H}\right] \mathrm{U}-69593$ binding in membranes from the mouse and guinea-pig, and $\sim 100$-fold more potent in the rat, while the $t$-butyl derivative was equipotent (Table 2). These findings indicate that unlike ligand binding to NMDA receptors. a phenolic hydroxyl group at C-12 affords optimal affinity at $k$-opioid receptors. This observation is consistent with previous studies (see Hite, 1989) demonstrating that among opiate alkaloids, "a phenolic $\mathrm{OH}$ group confers a higher affinity for opiate receptors compared to methoxylated analogs (e.g. morphine vs. codeine).

Since our previous studies indicate that the ability of ibogaine to attenuate the expression of morphine dependence is effected through an action at NMDA receptors (Popik et al.. 1995a). we compared the effects of $O$-desmethylibogaine and $O$ - $t$-butyl- $O$-desmethylibogaine in order to test this hypothesis. Thus. if these effects of ibogaine are NMDA receptor mediated. then it would be predicted that $O$-desmethylibogaine would be somewhat less active, and $O$ - $\boldsymbol{t}$-butyl- $O$-desmethylibogaine inactive. respectively. In confirmation of previous findings (Popik et al., 1995a), ibogaine inhibited naloxone-precipitated jumping in morphine-dependent mice, whilst the other ibogaine derivatives were inactive at the highest doses tested. Since higher doses of $O$-desmethylibogaine and $O$ - $t$-butyl- $O$ desmethylibogaine produced ataxia and convulsions, we were unable to use higher doses of these compounds.
Thus, these data support, but do not prove this hypothesid. Nonetheless. these data indicate that the interaction of ibogaine with $\kappa$-opioid receptors may not be responsible for this anti-addictive property of ibogaine since if $k$-opioid receptors were involved, then $O$-desmethylibogaine should be significantly more potent than ibogaine in attenuating naloxone-precipitated jumping. Likewise, based on the ability of ibogaine to interact with $\sigma$ receptors (Bowen et al., 1995: Mach et al.. 1995: Popik et al., 1995b), it might be hypothesized that the ability of ibogaine to inhibit naloxone-induced jumping in morphine-dependent mice might be mediated through this system. However, since the affinity of $O$ - $t$-butyl- $O$-desmethylibogaine for $\sigma$ receptors $\left(K_{1}\right.$ for $\sigma_{1}=3.5 \pm 1.3 \mu \mathrm{M} ; K_{1}$ for $\sigma_{2}=346 \pm 9 \mathrm{nM}$ [W.D. Bowen, personal communication]) is similar to that of ibogaine ( $K_{\mathrm{i}}$ for $\sigma_{1}=8.5 \pm 1.1 \mathrm{nM} ; K_{\mathrm{i}}$ for $\sigma_{2}=201$ $\pm 23 \mathrm{nM}$ [Bowen et al.. 1995]), it appears that $\sigma$ receptors are not involved in this action of ibogaine. It must be noted that naloxone-precipitated withdrawal is a complex phenomenon, and only one measure (jumping) was examined in the present study. Whether other withdrawal-associated measures are differentially affected by ibogaine and its derivatives is unknown. Moreover, the effect of substitution of the 12-methoxy moiety on blood-brain barrier permeability is unknown. Nonetheless. based on structural considerations $O$-t -butyl- $O$-desmethylibogaine should be more and $O$-desmethylibogaine less lipophilic than ibogaine, respectively. The observation that both $O$ - $t$-butyl$O$-desmethylibogaine and $O$-desmethylibogaine produced convulsions suggests that these compounds do cross the blood-brain barrier.

Anecdotal reports indicate ibogaine interrupts addiction to a wide variety of abused substances, and most preclinical data are consistent with these reports (Glick et al, 1991. 1994: Lotsof, 1985. 1986. 1995; Cappendjik and Dzoljic, 1993: Rezvani et al.. 1995: Sershen et al.. 1993). This pharmacological profile is similar to that reported for NMDA receptor antagonists (Trujillo and Akil, 1995). and raises the possibility that the claimed anti-addictive properties of ibogaine are mediated by voltage-dependent block of NMDA receptors. However. unlike prototypical NMDA receptor antagonists (MK-801), pharmacologically relevant concentrations of ibogaine interact with a number of systems implicated in tolerance and dependence phenomena. The availability of ibogaine derivatives that exhibit differing affinities for NMDA receptors provides a potential means of localizing the molecular targets responsible for the putative anti-addictive properties of the parent alkaloid.

\section{References}

Aceto. M.D. E.R. Bowman. L.S. Harris and E.L. May, 1990. Dependence studies of new compounds in the rhesus monkey, rat and mouse (1989), NIDA Res. Monogr. 95. 578.

Bartlett, M.F.. D.F. Dickel and W.I. Taylor. 1958. The alkaloids of Tabemanthe iboga. Part IV. The structures of ibogamine, ibogaine. tabernanthine and voacangine, J. Am. Chem. Soc. 80, 126. 
Ben-Eliyahu, S., P. Marek, A.L. Vaccarino. J.S. Mogil, W.F. Sternberg and J.C. Liebeskind, 1992, The NMDA receptor antagonist MK-801 prevents long-lasting non-associative morphine tolerance in the rat. Brain Res. 575, 304. (N)

Bormann. J.. 1989. Memantine is a potent blocker of $N$-methyl-D-aspartate (NMDA) receptor channels. Eur. J. Pharmacol. 166, 591.

Bowen. W.D.. B.J. Vilner, W. Williams, C.M. Bertha. M.E. Kuehne and A.E. Jacobson. 1995. Ibogaine and its congeners are $\sigma_{2}$ receptorselective ligands with moderate affinity. Eur. J. Pharmacol. 279. RI.

Cappendijk. S.L.T. and M.R. Dzoljic, 1993, Inhibitory effects of itogaine on cocaine self-administration in rats. Eur. J. Pharmacol. 241. 261

De Costa. B.. C. George. R.B. Rothman. A.E. Jacobson and K.C. Rice. 1987. Synthesis and absolute configuration of optically pure enantiomers of a kappa opioid receptor selective agonist. FEBS Lett. 223. 335.

Deecher. D.C.. M. Teitler. D.M. Soderlund. W.G. Bornmann. M.E. Kuehne and S.D. Glick. 1992. Mechanisms of action of ibogaine and harmaline congeners based on radioligand binding studies. Brain Res. 571. 242.

Dzoljic. E.D.. C.D. Kaplan and M.R. Dzoljic. 1988. Effect of ibogaine on naloxone-precipitated withdrawal syndrome in chronic morphine dependent rats, Arch. Int. Pharmacodyn. Ther. 294, 64.

Francés. B.. R. Gout. J. Cros and J.M. Zajac. 1992. Effects of ibogaine on naloxone-precipilated withdrawal in morphine-dependent mice. Fund. Clin. Pharmacol. 6. 327.

Glick. S.D.. K. Rossman, S. Steindorf. I.M. Maisonneuve and I.N. Carlson. 1991. Effects and aftereffects of ibogaine on morphine self-administration in rats, Eur. J. Pharmacol. 195, 341.

Glick, S.D.. K. Rossman, N.C. Rao. 1.M. Maisonneuve and J.N. Carlson. 1992. Effects of ibogaine on acute signs of morphine withdrawal in rats: independence from tremor. Neuropharmacology 31. 497.

Glick, S.D.. M.E. Kuehne. J. Raucci. T.E. Wilson. D. Larson. R.W Keller Jr. and J.N. Carlson. 1994. Effects of iboga alkaloids on morphine and cocaine self-administration in rats: relationship to tremorigenic effects and to effects on dopamine release in nucleus accumbens and striatum. Brain Res. 657. 14.

Higgins, G.A.. P. Nguyen and E.M. Sellers. 1992. The NMDA antagonist dizocilpine (MK-801) attenuates motivational as well as somatic aspects of naloxone precipitated opioid withdrawal. Life Sci. 50. PL 167.

Hite, G.J.. 1989, Analgesics, in: Principles of Medicinal Chemistry (3rd Ed.). ed. W.O. Foye (Lea \& Febiger, Philadelphia) p. 239.

Kolesnikov. Y.A., M.-L. Maccecchini and G.W. Pasternak, 1994, 1Aminocyclopropanecarboxylic acid (ACPC) prevents $\mathrm{mu}$ and delta opioid tolerance, Life Sci. 55, 1393.

Kornhuber, J.. J. Bormann, W. Retz. M. Hubers and P. Riederer. 1989 , Memantine displaces [ $\left.{ }^{3} \mathrm{H}\right] \mathrm{MK}-801$ at therapeutic concentrations in postmortem human frontal cortex. Eur. J. Pharmacol. 166, 589.

Lahti, R.A., M.M. Mickelson. J.M. McCall and P.F. Von Voigtlander, 1985, [ $\left.{ }^{3} \mathrm{H}\right] \mathrm{U}-69593$, a highly selective ligand for the opioid kappa receptor, Eur. J. Pharmacol. 109, 281.

Lipkowski, A.W., H. Nagase and P.S. Portoghese, 1986, A novel pyrrole synthesis via reaction of ketones with $\mathrm{N}$-aminoimides, Tetrahedron Lett. 27, 4257.

Lotsof, H.S., 1985, Rapid method for interrupting the narcotic addiction syndrome. U.S. Patent 4,499,096.

Lotsof, H.S.. 1986. Rapid method for interrupting the cocaine and amphetamine abuse syndrome. U.S. Patent 4.587.243.

Lotsof, H.S., 1995, Ibogaine in the treatment of chemical dependency disorders: clinical perspectives. Multidisciplin. Assoc. Psychedelic Stud. 5,16

Mach, R.H., C.R. Smith and S.R. Childers, 1995. Ibogaine possesses a selective affinity for $\sigma_{2}$ receptors, Life Sci. 57, PL 57.

Marek, P.. S. Ben-Eliyahu, M. Gold and J.C. Liebeskind. 1991. Excitatory amino acid antagonists (kynurenic acid and MK-801) attenuate the development of morphine tolerance in the rat, Brain Res. 547, 77.
Mash. D.C., J.K. Staley, J.P. Pablo. A.M. Holohean, J C. Hackman and R.A. Davidoff. 1995. Properties of ibogaine and its principal metabolite (12-hydroxyibogamine) at the MK-801 binding site of the NMDA receptor complex. Neurosci. Lett. 192. 53

Nock. B. A.L. Giordano. T.J. Cicero and L.H. O'Connor. 1990. Affinity of drugs and peptides for $\mathrm{C}-69.593$-sensitive and -insensitive kappa opiate binding sites: the U-69.593-insensitive site appears to be the beta endorphin-specific epsilon receptor. J. Pharmacol. Exp. Ther. 254. 412 .

Pearl. S.M.. K. Herrick-Davis. M. Teitler and S.D. Glick, 1995. Radioligand-binding study of noribogaine. a likely metabolite of ibogaine. Brain Res. 675. 342.

Popik. P.. R.T. Layer. L. Fossom. M. Benveniste. B. Getter-Douglass, J.M. Witkin and P. Skolnick, 1995a. NMDA antagonist propertics of the putative antiaddictive drug. ibogaine. J. Pharmacol. Exp. Ther. 275. 753 .

Popik. P.. R.T. Layer and P. Skolnick. 1995b. 100 years of ibogaine: neurochemical and pharmacological actions of a putative anti-addictive drug. Pharmacol. Rev. 47. 235.

Popik. P.. R.T. Layer and P. Skolnick. 1994. The putative anti-addictive drug ibogaine is a competitive inhibitor of $\left[{ }^{3} \mathrm{H}\right] \mathrm{MK}-801$ binding to the NMDA receptor complex. Psychopharmacology 114, 672.

Popik. P. and P. Skolnick. 1995. The NMDA antagonist memantine blocks the expression and maintenance of morphine dependence. Pharmacol. Biochem. Behav. (in press).

Rasmussen. K.. R.W. Fuller. M.E. Stockton. K.W. Perry, R.M. Swinford and P.L. Ornstein, 1991. NMDA receptor antagonists suppress behaviors but not norepinephrine turnover or locus coeruleus unit activity induced by opiate withdrawal. Eur. J. Pharmacol. 197, 9.

Repke. D.B.. D.R. Artis. J.T. Nelson and E.H. Wong, 1994, Abbreviated ibogaine congeners. Synthesis and reactions of Tropan-3-y1-2- and -3-indoles. Investigation of an unusual isomerization of 2-substituted indoles using computational and spectroscopic techniques, J. Org. Chem. 59. 2164.

Rezvani. A.H.. D.H. Overstreet and Y.W. Lee. 1995. Attenuation of alcohol intake by ibogaine in three strains of alcohol preferring rats. Pharmacol. Biochem. Behav. 52. 615.

Sershen. H.. A. Hashim. L. Harsing and A. Lajtha, 1992, Ibogaine antagonizes cocaine-induced locomotor stimulation in mice, Life Sci. 50. 1079.

Sershen. H., A. Hashim and A. Lajtha, 1993, Ibogaine reduces preference for cocaine consumption in C57BL/6By mice, Pharmacol. Biochem. Behav. 47. 13.

Sharpe. L. and J. Jaffe. 1990 . Ibogaine fails to reduce naloxone-precipitated withdrawal in the morphine-dependent rat, NeuroReport 1. 17.

Sweetnam. P.M., J. Lancaster, A. Snowman, J.L. Collins, S. Pershke, C. Bauer and J. Ferkany. 1995. Receptor binding profile suggests multiple mechanisms of action are responsible for ibogaine's putative anti-addictive activity, Psychopharmacology 118, 369.

Tiseo, P.J. and C.E. Inturrisi. 1993. Attenuation and reversal of morphine tolerance by the competitive $N$-methyl-D-aspartate receptor antagonist. LY274614, J. Pharmacol. Exp. Ther. 264, 1090.

Tiseo. P.J., J. Cheng. G.W. Pasternak and C.E. Inturrisi. 1994, Modulation of morphine tolerance by the competitive $N$-methyl-D-asparate receptor antagonist LY274614: assessment of opioid receptor changes. J. Pharmacol. Exp. Ther. 268, 195.

Trujillo. K.A. and H. Akil. 1991. Inhibition of morphine tolerance and dependence by the NMDA receptor antagonist MK-801. Science 251. 85.

Trujillo. K.A. and H. Akil. 1995. Excitatory amino acids and drugs of abuse: a role for $N$-methyl-D-aspanate receptors in drug rolerance. sensitization and physical dependence. Drug Alcohol Depend. 38. 139.

Zetler. G.. G. Singbarl and L. Schlosser. 1972. Cerebral pharmacokinetics of tremor-producing harmala and iboga alkaloids, Pharmacology 7. 237. 